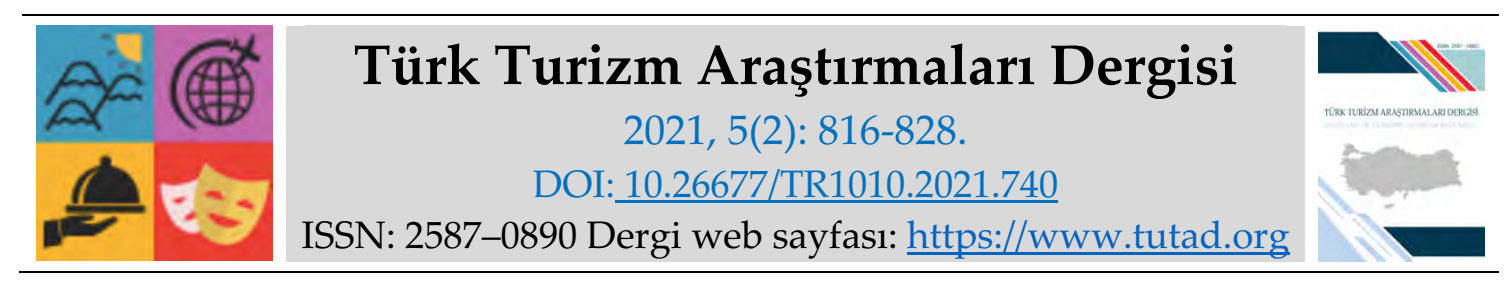

ARASTTIRMA MAKALESI

\title{
Burdur Kentinin Markalaşmasında Soyut ve Somut İmaj Unsurlarının Belirlenmesi
}

Dr. Öğr. Üyesi Tülay ÖZKAN, Burdur Mehmet Akif Ersoy Üniversitesi, Sosyal Bilimler MYO, Burdur, e-posta: tulayozkan@mehmetakif.edu.tr

ORCID: https://orcid.org/0000-0002-2411-0218

Dr. Öğr. Üyesi Burcu ALAN, Burdur Mehmet Akif Ersoy Üniversitesi, Sosyal Bilimler MYO, Burdur, e-posta: burcuozkara@mehmetakif.edu.tr

ORCID: https://orcid.org/0000-0002-5633-4320

Öz

Bu çalışmanın amacı, Burdur kentinin markalaşmasını sağlayacak olan soyut ve somut değerlerin farkındalık düzeylerinin anket yoluyla Burdur'da yaşayan kişilere uygulanarak ortaya çıkarılmasıdır. Çalışma Eylül - Aralık 2020 tarihleri arasında Burdur'da yaşayan ya da Burdur'da daha önce yaşamış/bulunmuş gönüllü katılımcılara anket yöntemiyle yapılmıştır. Çalışmaya toplamda 545 kişi katılmıştır. Verilerin analizi için frekans analizleri ve ortalamalar hesaplanarak değerlendirmeler yapılmıştır. Araştırmada Burdur'un marka farkındalığı en yüksek somut unsurları Salda Gölü ve Burdur Şiş'tir. Soyut unsurları ise sakinliği, güvenli ve temiz bir kent olması olarak belirlenirken; şehrin avantajlı yanları ise üniversitesi, doğal güzellikleri, eğitim imkanları, yemekleri ve tarihsel zenginliği ön plana çıktığı tespit edilmiştir. Araştırma sonucunda yapılan tespitlere göre Burdur kentinin öne çıkan soyut ve somut değerleri üzerinden bunların markalaşması için neler yapılabilir konusunda değerlendirmelerde bulunulmuştur.

Anahtar Kelimeler: Burdur, Kent Markası, Markalaşma, Marka İmajı, Marka Farkındalığı.

Makale Gönderme Tarihi: 14.02.2021

Makale Kabul Tarihi: 02.06.2021

\section{Önerilen Atıf:}

Özkan, T. ve Alan, B. (2021). Burdur Kentinin Markalaşmasında Soyut ve Somut İmaj Unsurlarının Belirlenmesi, Türk Turizm Araştırmaları Dergisi, 5(2): 816-828.

(C) 2021 Türk Turizm Araştırmaları Dergisi. 


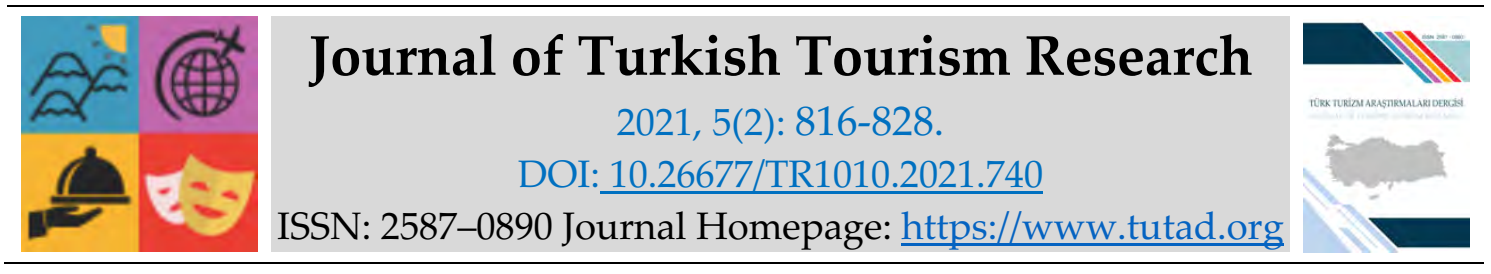

\title{
RESEARCH PAPER
}

\section{Determination of Tangible and Intangible Images in Branding of Burdur City}

Assistant Prof. Dr. Tülay ÖZKAN, Burdur Mehmet Akif Ersoy University, Social Sciences Vocational School, Burdur, e-mail: tulayozkan@mehmetakif.edu.tr ORCID: https://orcid.org/0000-0002-2411-0218

Assistant Prof. Dr. Burcu ALAN, Burdur Mehmet Akif Ersoy University, Social Sciences Vocational School, Burdur, e-mail: burcuozkara@mehmetakif.edu.tr

ORCID: https://orcid.org/0000-0002-5633-4320

\begin{abstract}
The purpose of this study is to reveal the awareness levels of abstract and concrete values that will enable the branding of the city of Burdur by applying them to the people living in Burdur through a survey. The study was conducted using a questionnaire method with volunteer participants who lived in Burdur or lived / been in Burdur between September and December 2020. A total of 545 people participated in the study. For the analysis of the data, frequency analyzes and averages were calculated and evaluations were made. In the research, the concrete elements of Burdur with the highest brand awareness are Salda Lake and Burdur Şiş. While intangible image elements are determined as calmness, safe and clean city; The advantageous sides of the city are the university, natural beauties, education, food and historical richness. According to the findings made as a result of the research, evaluations were made on what can be done for the branding of the prominent abstract and concrete values of the city of Burdur.
\end{abstract}

Keywords: Burdur, City Brand, Branding, Brand Image, Brand Awareness.

Received: 14.02 .2021

Accepted: 02.06.2021

\section{Suggested Citation:}

Özkan, T. and Alan, B. (2021). Determination of Tangible and Intangible Images in Branding of Burdur City, Journal of Turkish Tourism Research, 5(2): 816-828.

(C) 2021 Türk Turizm Araştırmaları Dergisi. 


\section{Gíriş}

Sosyolojik değişimler, rekabetin özellikle turizm alanında kentler arasında da yaşanmaya başlaması, küreselleşme ve beraberinde hayatımıza getirileri günümüzde kentlerde kendilerine özgü yönleriyle markalaşma telaşına sebep olmuştur. Kentlerin arasında yaşanan yoğun rekabetin sebeplerinden birisi de dünya refahından pay alarak yeni kitlelerin zihninde yer edinmektir. Bunun da yolu kendine has endemik özellikleri ile markalaşmak ve bununla beraber yaratılan olumlu imajdır. Küreselleşme artık bir dünya gerçeğidir ve farkında olsak da olmasak da bu gerçeğin içinde yer alınmaktadır. Küreselleşen dünyada yer edinebilmek için kentlerin diğer kentlerle iletişim içerisinde olmaları, dışa açık tutum izlemeleri gereklidir. Bunun nedeni ise markalaşmanın neredeyse kardeşi durumunda olan pazarlamadır. İki kavram birbirinden ayrı düşünülememektedir. Tutundurmanın sağlanabilmesi için başarılı bir imaj ve pazarlama yönetimi yapılmalıdır. Ülkeler birbirleri ile olan rekabetine kentler ile devam etmektedir (Aktuğlu, 2004; Özdemir ve Karaca, 2009; Avcılar ve Kara, 2015).

Markalaşmak, belirli farklılıklar neticesinde müşteriler tarafından rakiplerine karşı tercih edilerek değer kazanmaktır. Bir şehrin markalaşması ise, şehrin tüm kültürel, ticari ve siyasi kaynaklarının hedef kitlenin zihninde değer kazanmasıdır. Bu süreç, doğal kaynakları, doğayı, turizmi, altyapıyı içerisinde barındırdığı için karmaşık bir süreçtir. Burada önemli olan husus, hedef kitlenin zihninde merak uyandırmak, farkındalık oluşturmak ve farklılaşarak, kente yönelik olumlu imaj yaratmaktır. Kent markası, "marka strateji ve tekniklerinden yararlanarak belirli bir şehrin hedef kitle zihninde sıradan bir yerleşim yeri olarak algilanması yerine, insanların yaşamlarını devam ettirmek, çalışmak, yatırım yapmak, eğitim almak ve ziyaret etmek isteyecekleri cazibe yaşam merkezlerine dönüştürülmesi için yürütülen tüm faaliyetlerdir" (Aaker, 1996; Fan, 2006: 10; Dinnie, 2011:7).

$\mathrm{Bu}$ çalışmada, Burdur kentinin marka olma gerekleri, unsurları ve bunların nasıl algılandığı incelenmiştir. Bunlardan yola çıkılarak Burdur kentinin somut ve soyut unsurları algısı ölçülmeye çalışılmıştır. Elde edilecek sonuçlara göre, Burdur'a yönelik kültürel birikimimiz göz önünde bulundurularak, Burdur kentinin marka değeri taşımaya en müsait değerlerinden olan (www.burdur.gov.tr; burdur.ktb.gov.tr), "Burdur Şiş, Burdur Gölü, Sagalassos Antik Kenti/ Ağlasun, Ceviz ezmesi, Salda gölü/ Yeşilova, Lavanta tarlaları, B’laca dokumaları (Alaca Dokumaları), Salep, Kibyra Antik Kenti/ Gölhisar vd." olgularının marka değeri taşıma düzeyleri değerlendirmeye alınmıştır. Ayrıca Burdur kentinin, bahsedilen rekabet ortamında diğer kentlerden ayrıldığı yönleri, değerleri ve bunların markalaşma düzeyleri ortaya çıkarılmaya çalışılmıştır. Araştırma sonucunda yapılan tespitlere göre Burdur kentinin öne çıkan soyut ve somut değerleri üzerinden markalaşması için neler yapılabilir konusunda değerlendirmelerde bulunulmaktadır.

\section{KENTLERIN MARKALAŞMASI}

Markanın günümüzde bilinen tanımı; mal ürünlerini ya da hizmet ürünlerini tanımlamayı ve ayırt edici özellikler kazandırmayı sağlayan isim, terim, işaret, sembol, şekillerin tümü olarak yapılabilir. Marka, mal ya da hizmet ürünün, rakiplerden farkını ortaya çıkarmasına yarayan tüm bileşenlerdir. Buna göre tüketici ya da müşteri, marka ile zihninde mal ya da hizmetle ilgili bir imaj oluşturmaktadır. Çünkü marka ile tüketicide güven duygusu gelişmektedir, bunun da en önemli sebebi markanın, ürün ile ilgili önceden kestirilebilen sonuçlar ya da kullanım güvencesi vermesidir (Keller, 1998: 2; Kavas, 2004: 19; Moon ve Millison, 2004: 30). Ancak küreselleşen dünyada artık mallar ya da hizmetlerin yanı sıra kentlerin markalaşmasına ihtiyaç duyulmaktadır. 
Bir mal ya da hizmetin sağlamayı vaat ettiği faydaya ek olarak, markanın kullandığı isim, logo, terim gibi unsurlar ile yarattığı değerlere "marka değeri" denmektedir (Aaker, 1996: 8). Marka değerinin yaratılması başarılı bir markalaşma ile mümkündür. Markalaşma da marka yönetim sürecinin başarısı ile mümkündür (Aktuğlu, 2004: 42-43).

Kentler medeniyet, kültür ve sosyalliğin temelidir (Law, 2002: 1). Kentler, insanların sosyalleşme ihtiyacından doğmuştur ve onlara pek çok sosyal, kültürel ve ekonomik etkinlikler sunmaktadır. Bunlara ulaşım için bir hizmet faaliyeti gören turizm, insanlara boş zamanlarını eğlenceli geçirme imkânı vermektedir (Goeldner vd., 2000: 118). Turizm pazarlamasının en önemli etkeni kent pazarlamasıdır, çünkü bu doğrudan turist sayısına etki etmektedir. Bunun için kentlerin tanıtımı ve kentlerin markalaşması gerekmektedir. Şehir markası yaratma, marka stratejisi ve iletişimin birlikte kullanıldığı yeni bir kavramdır. Şehrin öne çıkan özelliklerinin, talebe yönelik olarak pazarlanması için şehre güçlü ve olumlu bir imaj yaratmadır (Tanlasa, 2005: 44). Destinasyon pazarlaması 1850'lerde Amerika'da, 1900'lerde de İngiltere ve Fransa'da uygulanmaya başlayan eski bir uygulamadır. Turizm gelirlerinden daha fazla pay alabilmek için ülkelerin giderek daha fazla uygulamaya başladığı destinasyon pazarlaması, aynı zamanda kentlerin de olumlu yönde gelişimine katkı sağlamaktadır (Kotler ve Gertner, 2002; Giritlioğlu ve Avcıkurt, 2010:76).

Kent markalaşması neden önemlidir ve neden kentler etapta markalaşmak için çaba sarf etmektedir sorusuna verilebilecek dört cevap vardır; bu cevaplardan ilki kent markası yaratımı destinasyonun diğer destinasyonlarla rekabet edebilmesini sağlamaktadır. İkincisi ise markalaşmanın gerçekleştiği destinasyonun geleceği için bir vizyon belirlemeye ve planlama için bir yön sağlamaya, bu vizyona ulaşılmasına yardımcı olacak farklı stratejilerin uygulanmasına yardımcı olmasıdır. Üçüncü cevap, destinasyon markasının paydaşlarla iş birliği için bir temel sağlamaktadır, paydaşların ortak bir hedef belirlemesine ve bu hedefe ulaşmak için birlikte çalışmasına zemin hazırlamaktadır. Böylece farklı paydaşlar birbirlerini tamamlayabilmekte ve güçlenebilmektedir. Son olası yanıt ise, markalaşmanın planlı bir kalkınma ve yenileme için yatırımların o bölgeye çekilmesini, turist kaynağından tam olarak nasıl yararlanılacağını belirlenmesini ve bölgesel kalkınmanın gerçekleşmesini sağlamasıdır. (Kavaratzis vd., 2014:5)

Şehir markası yaratma, modern marka yaratma stratejileri ve tekniklerinden faydalanmak suretiyle, bir kentin hedef kitle tarafından sıradan bir yerleşim yeri olarak algılanmasının önüne geçerek, insanların yaşama, çalışma, yatırım, eğitim gibi sebeplerle tercih edeceği bir yaşam merkezi haline getirilmesidir. (Dinnie, 2011:7). Böylelikle kent, farklı bir konuma bürünecek, hedef kitlenin tercihi durumuna gelecektir. Bu noktada oluşturulması gereken başka bir unsur da kent kimliğidir. Kent kimliği, şehrin çevresi ile karşllıklı ilişkisinden doğan, şehrin ruhunu yansıtan, marka yaratımı ile oluşturulmaya çalışılan markanın kendisi ve ortaya çıkardığı konumlandırmaya kişilik kazandıran ve markayı yaşatan bir unsurdur (Perry ve Wisnom, 2003:79; Karadağ ve Koçman, 2007:5; Kaypak, 2013:375-376).

$\mathrm{Bu}$ bahsedilenlerin tüketicinin zihninde yer bulabilmesi için, marka kent konumlandırma gerçekleştirilmelidir. Marka kent konumlandırma, hedef kitlenin zihnine kent markasının yerleşmesini sağlamak, kentin rakiplerinden farklılıklarını öne çıkartarak, kente olumlu bir imaj yaratmaktır (Braun, 2008:188; Işık ve Erdem, 2015:32).

Konu ile ilgili daha önce yapılmış çalışmalar incelendiğinde;

Demirgüneş ve Avcılar (2014), marka kent oluşturmanın avantajı olarak belirtilen kentte yaşayanların memnuniyet artışı üzerine Osmaniye ilinde bir araştırma yaparak, maddi yaşam koşullarından duyulan memnuniyet düzeyinin genel memnuniyeti etkileyen en önemli faktör olduğu bulgusuna ulaşmışlardır. 
Pektaş ve Karadeniz (2014), marka değeri yaratmada kent imajının etkisini, Gaziantep iline özgü olan baklava ile ölçerek, kent imajı, kentin marka değeri, tüketicilerin tekrar satın alma niyeti, genel marka değeri ve sadakati gibi değişkenler ile olan ilişkisini araştırmışlardır. Sonuçta "marka sadakatinin, kentin marka üzerinde yarattığı sadakatten daha etkin olduğu" sonucuna ulaşmışlardır.

Can ve Başaran (2014), Rize ilinde gerçekleştirdikleri çalışmalarında, “Kent Markası ve Marka İmajının Belirlenmesi, kent imajının hangi unsurlardan oluştuğunun tespiti ve kentin, fiziki ve soyut özellikleri ile kent halkının nasıl algılandığını" ölçmeye çalışmışlardır. Çalışma sonucunda ilinin tanınırlı̆̆ın turizm potansiyeli ile ilişkili olduğunu, ilin tanınırlığının ve imajının, turizm çeşitliliği ve gelirinin de artırdığı bulgusuna ulaşmışlardır.

Huang vd. (2013), New York ve Buffalo'da gerçekleştirdikleri çalışma sonucunda, alışveriş olanakları, gıda, kültür, sosyal etkinlikler, spor, doğa ve turizm aktiviteleri değişkenlerinin kent markası oluşturulması hususunda belirleyici olduğunu bulgusuna ulaşmışlardır.

Beyaz ve Boyraz (2020), Erzurum iline rakip iller belirleyerek aralarındaki marka konumlandırma farklarını ortaya koymaya yönelik, algılama haritalarını kullanarak bir çalışma yapmıştır. Sonuçta Erzurum ilinin marka konumu, rakip olarak belirlenen illere nazaran daha kötü çıkmıştır.

Köşker vd. (2019), Türkiye'nin en turistik illeri olan İstanbul, Antalya, Muğla, İzmir, Ankara, Nevşehir, Aydın, Denizli, Gaziantep ve Hatay illerinin marka kimlikleri inceleyerek, bu illerin marka kimliklerinde hangi renkleri kullandıkları, hangi turistik değer ve yerel sembollerle ön plana çıkardıkları, hangi sloganları kullandıkları ve logolarında kendilerini nasıl konumlandırdıkları hususunda bir çalışma yapmışlardır. Araştırma sonucunda; bu illerin tümünün tarihi ve kültürel değerlerini ön plana çıkarmaya çalıştıkları, bunun yanı sıra Gaziantep ve Hatay'ın gastronomik değerlerine de vurgu yaptıkları, bu illerin kent, belediye ve valilik logolarının birbirlerinden farklı olduğu, Ankara, Nevşehir ve Denizli'nin ise turistik sloganının bulunmadığı bulgularına ulaşmışlardır. Ayrıca İstanbul, Antalya ve Gaziantep'in kendilerine özgü turistik kentsel marka kimliğine sahip oldukları ortaya çıkmıştır.

Merrilees, Miller ve Herington (2009), çalışmalarında Avustralya bulunan Gold Coast City'de ikamet edenlerin marka tutumlarının nelerden etkilendiğini araştırmışlardır.

Cai (2002), çalışmasında "Ortak Markalama" olarak adlandırdığı bir kavramdan bahsederek, markalaşma için yeterli özelliği bulunmayan destinasyonların birlikte ortak bir marka belirleyerek pazarlanması fikrini ortaya atmıştır.

Koumara-Tsitsou ve Karachalis, N. (2021), geleneksel ve yerel ürünlerin sürdürülebilir turizm gelişimiyle arasındaki bağlantıyı ölçmeye çalışmış, paydaşların ve yerel halkın bu bağlamda etkisini de ilişkilendirmiştir. Çalışmasında geleneksel ve yerel ürünlerin markalaşma için kullanımında yerel girişimciliğin öneminden bahsetmiştir.

Florek, Hereźniak ve Augustyn (2021), çalışmalarında standartlaştırılmış, tek beden ve her şeye uyan metodolojilere başvurmak yerine, destinasyonun özelliklerine, isteklerine ve yeteneklerine uyarlanabilir uygulamalar yapılması gerektiğini savunmuşlardır.

Gartner, 2014 yılında yayınlanan çalışmasında Türkiye'ye yönelik bir tespitte bulunmuştur, katılımcllara Türkiye'ye ait fotoğraflar gösterildiğinde neresi olduğunu bilmeden çok etkilenmelerine rağmen, Türkiye'nin marka çağrışımının katılımcılarda negatif olduğunu öne sürmüştür.

Kent markasına yönelik çalışmalarda, kentin özelliklerinin ve sakinlerinin bu markalaşma sürecinde etkin rol oynadığını, marka kentlerin farklı özelliklerini ön plana çıkararak ziyaretçileri 
çektiğini, markalaşmanın yalnızca bir algıdan ibaret olmadığını, kente yönelik bir bilinç oluşturulması gerektiğini öne sürmektedirler. Ancak markalaşma için her şehrin farklı unsurlar barındırdığı göz önünde bulundurulmalı ve buna yönelik yöntemler uygulanmalıdır.

\section{YÖNTEM}

\section{Araştırmanın Amacı ve Soruları}

Araştırmanın amacı, Burdur kentinin markalaşmasını sağlayacak olan soyut ve somut imajları ile avantajlarının anket yoluyla Burdur'da yaşayan ya da yaşamış kişilere uygulanarak tespitidir. Bu bağlamda araştırma soruları;

- Burdur kentinin markalaşmaya değer soyut ve somut imaj unsurları nelerdir?

- Burdur kentinin markalaşmasında çekiciliğini artıracak olan avantajları nelerdir?

Bu çalışmada, yukarıda da belirtildiği üzere, Burdur kentinin markalaşması yolunda, soyut imaj unsurları ve avantajlarına yönelik katılımcıların algısı ölçülmeye çalışılarak, Burdur kentinin markalaşmasına en uygun değeri taşıma düzeyi yüksek olan somut imaj unsurları ortaya çıkarılacaktır. Bu bağlamda araştırmada Burdur'a özgü somut imaj unsurları olarak "Burdur Şiş, Sagalassos (Ağlasun), Ceviz ezmesi, Salda gölü/ Yeşilova Lavanta tarlaları, Fakir Baykurt ve Akçaköy, Keten helvası, Haşhaş ezmesi, Tahin, Su böreği, Sarı burma, B’laca dokumaları (Alaca Dokumaları), Salep, Kibriya / Gölhisar, Tarhana, Lokul (kömbe/çanak ekmeği), Teke yöresi folkloru, Sipsi, Mermer, Tarım ve hayvancılık, Üniversite, Salı pazarı, Burdur Gölü, Cura (Küçük Saz), Hacılar, Lisinia, Tefenni Barutlu Su, Karacaören Barajı Bucak Kervansarayı Salda Kayak Merkezi (Yeşilova), Burdur üzümü, pekmezi, yaprağı (dimrit, razakı), Aziziye Yörük Şenlikleri (güreş), Keşkek, Sarma aşı, Burdur İnsuyu Mağarası, Ağlasun Alabalık Tesisleri, Kestel Alabalık Tesisleri, Burdur Serenler Tepesi, Burdur Kuş Gözlem Evi, Pancar, Burdur şekeri ve Anason" ele alınmıştır.

\section{Evren ve Örneklem}

Araştırmanın evrenini Burdur'da yaşayan ya da Burdur'da daha önce yaşamış/bulunmuş kişiler oluşturmaktadır. Araştırma kamuya açık alanlarda yapılacağı için tesadüfi ve kolayda örnekleme yöntemi seçilmiştir. Anket formları gönüllülük esasına dayanarak yüz yüze uygulanmıştır.

Örneklem seçiminde tüketim yoğunluğu bakımından ağırlıklı olarak gençlere ulaşılmaya çalışılmıştır. Katılımcıların \%51'i erkek ve \%45'i 18-20 yaş, \%52'si 21-30 yaş, \%2'si 31-40 yaş aralığındadır. \%81'i üniversite mezunu, \%1'i lisansüstü ile \%17'si ilköğretim ve ortaöğretim mezunudur.

\section{Veri Toplama Araci}

Veri toplama aracı olarak anket tercih edilmiştir. Burdur kentine özgü somut ve soyut imajlar ile avantajların yer aldığı anket formundaki ifadeler, literatürdeki benzer çalışmalardan esinlenilerek (Karadağ ve Koçman, 2007; Özdemir ve Karaca, 2009; Demirel, 2014; Can, 2014; Köşker vd. 2019) tarafımızca Burdur'a özgü olarak hazırlanmıştır. Burdur Mehmet Akif Ersoy Üniversitesi Girişimsel Olmayan Klinik Araştırmalar Etik Kurulu'ndan 20.08.2020 tarihli GO 2020/199 Karar No'lu etik kurul raporu alınmıştır.

Anket soruları üç bölümden oluşmaktadır. 
- Birinci bölümde Burdur kentinin somut unsurları (3) Biliyorum/ Kullandım/gördüm, (2) Biliyorum/ kullanmadım/ görmedim, (1) Bilmiyorum/ duymadım'a doğru;

- İkinci bölümde Burdur kentinin soyut unsurları (5) Kesinlikle Katılıyorum'dan (1) Kesinlikle Katılmıorum'a doğru ve

- Son bölümde Burdur kentinin avantajlarını (5) Çok İyiden (1) Çok Kötüye doğru değerlendirmeleri istenmektedir.

Anket uygulanacak kişiler Burdur' da yaşayan ya da yaşamış/bulunmuş kişilerden oluşacağ 1 için, söz konusu değerler ile ilgili fikri olan kişiler olacaktır. Dolayısıyla markalaşmaya uygunluğun ayırdına varılabilecek deneyimde olacaklardır.

\section{Analiz Yöntemleri}

Toplanacak verilere ilişkin frekans analizleri ve ortalamalar hesaplanarak, yukarıda sayılan değerlerin marka değeri yaratma algısı, Burdur'un diğer kentlerden ayrıldığı yönleri, farklılıkları, değerleri ve bunların markalaşma düzeyi SPSS programı yardımıyla ölçülmüştür.

Somut unsurların farkındalık düzeylerinin sıralanması, tarafımızca geliştirilen aşağıdaki ölçüte göre yapılmıştır.

- (1) seçeneği, 01-10 yüzdelik arasında ise Marka Farkındalığ 1 Çok Yüksek

- (1) seçeneği, 11-20 yüzdelik arasında ise Marka Farkındalığı Yüksek

- (1) seçeneği, 21-30 yüzdelik arasında ise Marka Farkındalığ İyi

- (1) seçeneği, 31-40 yüzdelik arasında ise Marka Farkındalığ ${ }_{1}$ Orta

- (1) seçeneği, 41-50 yüzdelik arasında ise Marka Farkındalığı Düşük

- (1) seçeneği, 51-100 yüzdelik arasında ise Marka Farkındalığı Çok Düşük

Bunun dışında soyut unsurları ve kentin avantajları ortalamaları için Demirel (2014)'ün çalışmasında kullandığ 1-1,8 arası oldukça düşük; 1,8-2,6 arası düşük; 2,6-3,4 arası orta; 3,4-4,2 arası yüksek; 4,2-5,0 arası oldukça yüksek algı düzeyine göre değerlendirilmiştir.

\section{BULGULAR}

\section{Burdur Kentinin Somut Unsurları Bulguları}

Tablo 1'de Burdur kentinin somut unsurlarından en yüksek farkındalığa sahip olanlardan aza doğru sıralama yapılmıştır.

Tablo 1'de Burdur kentinin bilinirliği yüksek unsurlarının, katılımcılar tarafından farkındalığı, özetle daha öncesinde karşılaşıp/karşılaşılmadığı veya duyulup/duyulmadığı ölçülmeye çalışılmış ve marka farkındalığı çok yüksekten çok düşüğe doğru sıralanmıştır. Bu listede yer alan bütün unsurlar Burdur kentini diğer illerden ayıran bir farklılıktır. Buna göre bilinirliği en yüksek unsurlar; Salda gölü ve Burdur Şiş iken bilinirliği en düşük unsurlar ise; B'laca dokumaları (Alaca Dokumaları), Tefenni Barutlu Su, Fakir Baykurt ve Akça Köy, Lisinia ve Keten helvasıdır. Kentin yöneticileri bilinirliği yüksek unsurlar vasıtasıyla Burdur kentini marka kent haline getirebilirler. Marka farkındalığı yüksek çıkmayan unsurlar üzerinde durularak, bu unsurların da bilinirliğinin yükseltilmesi ve marka kent olma hususunda kullanılması düşünülebilir. 
Tablo 1. Somut Unsurların Farkındalık Düzeyleri

\begin{tabular}{|c|c|c|c|c|}
\hline Somut Unsurlar & (1) & $(2)$ & (3) & Farkındalık Düzeyi \\
\hline 1. Salda gölü/ Yeşilova & 6 & 28 & 66 & Marka Farkındalığı Çok Yüksek \\
\hline 2. Burdur Şiş & 9 & 18 & 73 & Marka Farkındalığı Çok Yüksek \\
\hline 3. Burdur Gölü & 11 & 18 & 71 & Marka Farkındalığı Yüksek \\
\hline 4. Üniversite & 12 & 13 & 75 & Marka Farkındalığı Yüksek \\
\hline 5. Salı pazarı & 12 & 16 & 72 & Marka Farkındalığı Yüksek \\
\hline 6. Ceviz ezmesi & 13 & 28 & 59 & Marka Farkındalığı Yüksek \\
\hline 7. Tarım ve hayvancilık & 16 & 31 & 53 & Marka Farkındalığı Yüksek \\
\hline 8. Burdur İnsuyu Mağarası & 20 & 33 & 47 & Marka Farkındalığı Yüksek \\
\hline 9. Lavanta tarlaları & 21 & 42 & 37 & Marka Farkındalığı İyi \\
\hline 10. Salep & 22 & 25 & 53 & Marka Farkındalığı İyi \\
\hline 11. Mermer & 23 & 33 & 44 & Marka Farkındalığı İyi \\
\hline 12. Tarhana & 24 & 22 & 54 & Marka Farkındalığı İyi \\
\hline 13. Tahin & 25 & 24 & 51 & Marka Farkındalığı İyi \\
\hline 14. Sagalassos/Ağlasun & 26 & 45 & 29 & Marka Farkındalığı İyi \\
\hline 15. Su böreği & 26 & 22 & 52 & Marka Farkındalığı İyi \\
\hline 16. Pancar & 26 & 27 & 47 & Marka Farkındalığı İyi \\
\hline 17. Burdur şekeri & 27 & 26 & 47 & Marka Farkındalığı İyi \\
\hline 18. Kibyra Antik Kenti/ Gölhisar & 30 & 39 & 31 & Marka Farkındalığı İyi \\
\hline 19. Salda Kayak Merkezi /Yeşilova & 30 & 35 & 35 & Marka Farkındalığı İyi \\
\hline 20. Keşkek & 32 & 24 & 44 & Marka Farkındalığı Orta \\
\hline 21. Haşhaş ezmesi & 34 & 28 & 38 & Marka Farkındalığı Orta \\
\hline 22. Burdur Serenler Tepesi & 34 & 28 & 38 & Marka Farkındalığı Orta \\
\hline 23. Burdur Kuş Gözlem Evi & 35 & 28 & 37 & Marka Farkındalığı Orta \\
\hline 24. Anason & 36 & 30 & 34 & Marka Farkındalığı Orta \\
\hline 25. Teke yöresi folkloru & 38 & 28 & 34 & Marka Farkındalığı Orta \\
\hline 26. Burdur üzümü, pekmezi, yaprağı (dimrit, razakı) & 38 & 26 & 36 & Marka Farkındalığı Orta \\
\hline 27. Sipsi & 39 & 26 & 34 & Marka Farkındalığı Orta \\
\hline 28. Ağlasun Alabalık Tesisleri & 39 & 31 & 30 & Marka Farkındalığı Orta \\
\hline 29. Lokul (kömbe/çanak ekmeği) & 40 & 24 & 36 & Marka Farkındalığı Orta \\
\hline 30. Sarı burma & 41 & 27 & 32 & Marka Farkındalığı Düşük \\
\hline 31. Sarma aşı & 42 & 25 & 33 & Marka Farkındalığı Düşük \\
\hline 32. Kestel Alabalık Tesisleri & 45 & 26 & 29 & Marka Farkındalığı Düşük \\
\hline 33. Cura (Küçük Saz) & 46 & 25 & 29 & Marka Farkındalığı Düşük \\
\hline 34. Hacilar & 46 & 25 & 29 & Marka Farkındalığı Düşük \\
\hline 35. Karacaören Baraj1 & 47 & 28 & 25 & Marka Farkındalığı Düşük \\
\hline 36. Aziziye Yörük Şenlikleri (güreş) & 48 & 28 & 24 & Marka Farkındalığı Düşük \\
\hline 37. Bucak Kervansarayı & 49 & 27 & 24 & Marka Farkındalığı Düşük \\
\hline 38. B'laca dokumaları (Alaca Dokumaları) & 52 & 27 & 21 & Marka Farkındalığı Çok Düşük \\
\hline 39. Tefenni Barutlu Su & 52 & 26 & 22 & Marka Farkındalığı Çok Düşük \\
\hline 40. Fakir Baykurt ve Akça köy & 53 & 30 & 17 & Marka Farkındalığı Çok Düşük \\
\hline 41. Lisinia & 53 & 21 & 26 & Marka Farkındalığ 1 Çok Düşük \\
\hline 42. Keten helvasi & 55 & 27 & 18 & Marka Farkındalığ 1 Çok Düşük \\
\hline
\end{tabular}

\section{Burdur Kentinin Soyut Unsurları Bulguları}

Tablo 2'de Burdur kentinin soyut unsurlarına katılımcların katılma oranları verilmiştir. İlk iki sırada yüksek algı düzeyinde Burdur kentinin sakinliği ve güvenli ortaya çıkmıştır. Bunun yanı sıra kentin temizliği orta düzeyde değerlendirilirken ucuz, dışa dönük, modern ve gelişmiş olması unsurlarının düşük olması kentin cazibesini düşüren unsurlardır. 
Tablo 2. Soyut İmaj Unsurları Bulguları

\begin{tabular}{|l|c|c|c|c|}
\hline \multicolumn{1}{|c|}{ Soyut Unsurlar } & N & Ortalama & S. Sapma & İmaj Alg1 Düzeyi \\
\hline (1) Sakin & 545 & 4,12 & 1,190 & Yüksek \\
\hline (2) Güvenli & 545 & 3,45 & 1,303 & Yüksek \\
\hline (3) Temiz & 545 & 3,11 & 1,238 & Orta \\
\hline (4) Ucuz & 545 & 2,32 & 1,441 & Düşük \\
\hline (5) Dişa Dönük & 545 & 2,26 & 1,286 & Düşük \\
\hline (6) Modern & 545 & 2,17 & 1,291 & Düşük \\
\hline (7) Gelişmiş & 545 & 2,13 & 1,282 & Düşük \\
\hline
\end{tabular}

\section{Burdur Kentinin Avantajları Bulguları}

Tablo 3'de Burdur kentinin avantajları bulguları en yüksek ortalamadan en düşüğe doğru sıralanmıştır.

Tablo 3. Burdur Kentinin Avantajları Bulguları

\begin{tabular}{|l|c|c|c|c|}
\hline \multicolumn{1}{|c|}{ Özellik } & N & Ortalama & S. Sapma & İmaj Alg1 Düzeyi \\
\hline (1) Üniversite & 545 & 3,31 & 1,358 & Orta \\
\hline (2) Doğal güzellikler & 545 & 3,25 & 1,299 & Orta \\
\hline (3) Eğitim imkânları & 545 & 3,15 & 1,259 & Orta \\
\hline (4) Yemekleri & 545 & 3,04 & 1,358 & Orta \\
\hline (5) Tarihsel zenginlik & 545 & 3,01 & 1,338 & Orta \\
\hline (6) Çevre temizliği & 545 & 3,00 & 1,254 & Orta \\
\hline (7) Coğrafi konumu & 545 & 2,84 & 1,341 & Orta \\
\hline (8) Ulaşımın rahatlığı & 545 & 2,82 & 1,390 & Orta \\
\hline (9) Turizm destinasyonlarına yakınlığ1 & 545 & 2,70 & 1,342 & Orta \\
\hline (10) Spor aktiviteleri & 545 & 2,62 & 1,261 & Orta \\
\hline (11) Kültürel etkinlikler & 545 & 2,60 & 1,283 & Orta \\
\hline (12) Sağlık imkânları & 545 & 2,57 & 1,279 & Düşük \\
\hline (13) Konaklama imkânları & 545 & 2,54 & 1,328 & Düşük \\
\hline (14) Sanayisi & 545 & 2,52 & 1,259 & Düşük \\
\hline (15) İklimi & 545 & 2,48 & 1,319 & Düşük \\
\hline (16) Sanatsal etkinlikler & 545 & 2,47 & 1,242 & Düşük \\
\hline (17) Planlı kentleşme & 545 & 2,42 & 1,218 & Düşük \\
\hline (18) Alışveriş imkânları & 545 & 2,00 & 1,197 & Düşük \\
\hline (19) Eğlence imkânları & 545 & 1,91 & 1,150 & Düşük \\
\hline
\end{tabular}

Burdur kentinin ortalama değeri en yüksek olan avantajları üniversite 3.31 ortalama ile birinci sırada yer alırken sırasıyla doğal güzellikler 3.25, eğitim imkanları 3.15, yemekleri 3.04 ve tarihsel zenginliği 3.01'dir. Yüksek imaj alg1 düzeyinden düşüğe doğru yapılan bu sıralamada Burdur Kentinin avantajları sıralamasında en yüksek ortalama değerinin bile 3.31 olduğu görülmektedir.

Burdur kentinin en zayıf olduğu konular ise eğlence (1.91), alışveriş imkânlarının azlığı (2.00), planlı kentleşme (2.42), sanatsal etkinlikler (2.47), ve iklimi (2.48) olarak karşımıza çıkmaktadır. Burdur kentinin ulaşım kolaylığı avantajı, tarihsel zenginlik gibi diğer avantajlarla birleştirilerek kent markası oluşumunda, özellikle üniversite ile ilişkilendirilerek kullanılabilir. Ancak burada dezavantajların, avantajların önüne geçmesi engellenmelidir. Örneğin çalışma sonucunda ortaya 
çıkan eğlence imkânlarının azlığı, turizm sezonunda farklı trendlerle desteklenerek, engelleyici bir unsur olmasının önüne geçilebilir.

\section{SONUÇ, TARTIŞMA ve ÖNERİLER}

Modern insan için turistik amaçlı geziler artık bir lüksten ziyade gereklilik haline dönüşmüş durumdadır. Dünyada son yıllarda insanlar an biriktirmeye yönelik seyahatlere daha fazla çıkmaya, bu noktada insanların tatil anlayışı da değişiklik göstermeye başlamıştır. Eskiden olan deniz ve güneş tatili anlayışı farklı formlara bürünmeye başlamıştır. Bu nedenle bu turistik anlayışa sahip olmayan kentlerin de turizmden pay almaya başladığını görebilmekteyiz. Tabi bu durum kentler arası rekabeti de daha da artırmaktadır. Çünkü eskiden yarışta olmayan kentler de bu rekabetin içerisinde yer almaya başlamışlardır. Bu rekabette öne çıkmak, özellikle yarışa yeni katılan kentler için biraz daha zordur. Bu zorluğun üstesinden gelebilmek de marka kent oluşturma ile mümkün olabilmektedir.

Her kent gerek yapısı gerek yaşayan sakinleri gerek de tarihi ve turistik güzellikleri ile birbirinden ayrılmaktadır ve pazarlaması yapılırken bu ayırt edici unsurlar ön plana çıarılmalıdır. Ancak burada dikkat edilmesi gereken bir husus, tüketiciye, karşılanabileceğinden fazla fayda beklentisi sunarak, onu hayal kırıklığına uğratmamaktır. Aksi takdirde marka imajı zarar görmektedir.

Bu çalışmada Burdur kentinin kent markası oluşturma yolunda öne çıkarılabilecek özelliklerinin farkındalığı ölçülmeye çalışılmıştır. İlk tabloda verilen Burdur'a ait endemik unsurların farkındalığına bakıldığında, Burdur Şiş ya da Salda Gölü gibi pazarlaması iyi yapılan unsurların farkındalığı beklenildiği üzere yüksek çıkmıştır. Buradan hareketle aslında Burdur'a ait diğer unsurların da aynı şekilde ön plana çıkartılmasının, bunlara ait farkındalığı da yükselteceğini söyleyebiliriz. Örneğin Burdur Gölü'nün aktif kullanımı ve gölün simgesi haline gelen Dikkuyruk adlı su kuşunun farkındalığı oluşturulabilir. Her yıl düzenlenen Burdur Göl Festivali'nin daha fazla duyurulması sağlanarak, farklı ve dikkat çekici etkinliklerle hatta medyatik isimlerle desteklenerek, farkındalık yaratılması sağlanabilir. Bunların dışında Kibriya, Sagalassos ve Hacılar Höyüğü gibi tarihi değere sahip yerlerin farkındalığının düşük çıkması, buralara hak ettikleri pazarlama unsurlarının sağlanmadığını göstermektedir. Aynı söylem en az Burdur Şiş kadar popüler olması gerekirken daha alt sıralarda olan Ceviz Ezmesi için de geçerlidir. Ya da çok zengin ve köklü bir geçmişe sahip Teke Yöresi folklorunun, hak ettiği üne kavuşamaması da aynı nedenledir. Kısaca özetlemek gerekirse, farkındalığı düşük çıkan bütün unsurların pazarlama eksiği nedeni ile bilinmediği söylenebilir. Bu değerlere yönelik reklam ve pazarlama çalışmaları yapılarak, hak ettikleri üne kavuşturulması sağlanabilir. Örneğin insanlık tarihinin en eski yerleşim birimleri arasında kabul edilen Hacılar Höyüğ̈̈'nde, ya da önemli antik kentler içerisinde bulunan Kibriya ve Sagalassos'ta, ulusal ya da uluslararası bir kültür-sanat etkinliği düzenlenerek, son dönemin popüler pazarlama araçları arasında yer alan sosyal medya kullanılarak hem söz konusu yerlerin hem de Burdur'un farkındalığı düşük çıan diğer unsurlarının bu vesileyle tanıtımı yapılabilir. Benzer bir durum İnsuyu Mağarası için de geçerlidir. Dünyanın turizm potansiyeline sahip en derin mağaraları arasında bulunan İnsuyu Mağarası hem tanıtımının yeterli şekilde yapılmaması hem de iyi korunamaması dolayısıyla hak ettiği üne sahip değildir. Son yıllarda yağışların azalması ve yanlış sulama politikaları sebebi ile mağara içinde bulanan göllerin suları çekilmiş ve mağara eski güzelliğini kaybetmeye başlamıştır. Öncelikle bu duruma çözüm bulunmalı, gereksiz ve hatalı sulama uygulamalarının önüne geçilmeli, İnsuyu Mağarasına eski görselliği geri kazandırılmalıdır. Bu hem mağaranın farkındalığının artırılmasına hem de gelecekte karşılaşılması muhtemel su sorununun önüne geçmeye katkı sağlayacaktır. 
Burdur kentinin soyut imaj unsurlarına bakıldığında, Burdur'un sakin ve güvenli bir kent olması özellikleri kullanılarak, yükselen trend 'Cittaslow' uygulamasına dahil edilebilir (cittaslowturkiye.org). Böylelikle Burdur'un dezavantajları avantaja dönüştürülebilir. Yine kentin temiz olması turizm için önemli bir unsur oluştururken kentin ucuz, dışa dönük, modern ve gelişmiş olması algılarının düşük olması bir dezavantajdır.

Burdur kentine ait avantajlar, üniversite, doğal güzellikler, eğitim imkânları, yemekleri, tarihsel zenginlik ve çevre temizliği, kentin en zayıf olduğu konular ise planlı kentleşme, sanatsal etkinlikler, eğlence ve alışveriş imkânlarının azlığı, iklimidir. Bu durum Demirel (2014)'ün sonuçlarıyla benzerdir. Burdur kentinin ulaşımının kolay olması, tarihi ve kültürel zenginliklerle birleştirilerek kent markası oluşumunda, üniversite ile ilişkilendirilerek kullanılmalıdır. Önceden de belirtildiği gibi, eğlence ya da alışveriş imkânlarının azlığı gibi çözümü basit konular, kenti ileri gelenleri tarafından alt yapı yatırımları ile desteklenerek, kent için engelleyici unsur olmaktan çıkarılmalıdır. Bunun yanı sıra kente turistik amaçla gelenlerin konaklama ihtiyaçlarını karşılayacak yatırımlar yapılmalı ve teşvik edilmelidir. Böylelikle kente yönelik genelde yapılan günü birlik geziler uzun vadeye yayılmış olacaktır.

Burdur kenti küçük bir kent kategorisindedir. Ancak kentin gelişmişliği kişilere göre değişiklik gösterebilecek bir kavramdır. Herhangi bir kente giden bir kişi, öncelikle o kenti kendi yaşadığ 1 kentle, sonrasında da öncesinde ziyaret ettiği kentlerle kıyaslayacaktır. Bu noktada kişiden kişiye değişiklik gösterebilen bir gelişmişlik düzeyi algısı ile karşılaşılacaktır. Özellikle büyük kentlerde yaşayan insanların özlem duyduğu küçük ve sakin kent özlemi bu noktada Burdur kenti için bir avantaja dönüştürülebilir.

Kent markası yaratma konusunda son yıllarda Salda Gölü'nün çok yoğun olarak kullanıldığını, hatta Lavanta Bahçeleri ve Burdur Şiş ile de desteklendiğini, bu konuda oldukça başarılı olunduğunu da görmekteyiz. Burdur'un her biri Salda Gölü ya da Burdur Şiş kadar popülerliği hak eden ve buna uygun diğer endemik değerlerinin de aynı şekilde pazarlanması ile kent markası yaratma hususunda çok başarılı olunacağı aşikârdır. Bunu başarmak için Salda Gölü'nün popülerliğinden yararlanılabilir. Salda Gölü sayesinde hali hazırda gelmeye ikna edilmiş olan ziyaretçilere, diğer destinasyonlar da gezdirilerek, tanıtımı sağlanabilir. Ziyaretçilere sunulacak olan ikramlar ise Burdur Şiş'in tekelinden çıkarılarak, yanında Burdur'a özgü diğer yiyecek alternatiflerinin de eklenmesi, hatta satışa sunulması hem farkındalık yaratmada hem de farklı bölgelere götürülmesi sağlanarak tanıtımında faydalı olacaktır.

Bu bağlamda Burdur'un tepe yöneticileri, belediyesi, ticari örgütleri, sivil toplum kuruluşları, üniversitesi ve sakinleri, Burdur'un kent markası oluşumu için dayanışma ve eşgüdüm içerisinde çalışmalıdır. Bilindiği üzere yalnızca marka oluşturmak yeterli olmamaktadır. Sonrasında destekleyici faaliyetlerle sürdürülebilir kılınmayan markalar unutulmaktadır. Bu durum kent markaları için de geçerlidir. Kent markasının yaratılmasının ardından sürdürülebilir kılınması da aynı dayanışma ve eşgüdümü gerektirmektedir. Bulgularda ortaya çıkan eksiklikler ivedilikle giderilmeli ve kenti destekleyecek sosyo-kültürel yatırımlar yapılmalıdır. Çünkü bir kentin yalnızca doğal güzelliklerinin ya da endemik özelliklerinin bulunması kent markası oluşturmak için yeterli olmamaktadır. Destinasyonu tercih eden misafirler, bunların yanı sıra sosyal ve kültürel unsurların da bulunmasına dikkat etmektedirler. Bu sebeple, sosyolojik etkileşimin doğru sağlanabilmesi için kent sakinlerinin de bu sürece dâhil edilmesi, onların da isteklerinin doğru anlaşılması gerekmektedir. Bunun yanlış yönlendirilmesi, gelecek olan misafirlerden rahatsız olacak kent sakinleri imajı yaratacak ve haliyle bu da kent markası imajını zedeleyecektir 


\section{KAYNAKÇA}

Aaker, D. A. (1996). Building Strong Brands. (1. Edition), New York: The Free Press.

Aktuğlu, I. K. (2004). Marka Yönetimi: Güçlü ve Başarılı Markalar İçin Temel İlkeler. İstanbul: İletişim Yayınları.

Avcılar, M. Y. Y. ve Kara, E. (2015). Şehir Markası Kavramı ve Marka Şehir Yaratma Stratejilerine Yönelik Literatür İncelemesi, Sosyal ve Beşerî Bilimler Araştırmaları Dergisi, 16(34): 76-94.

Beyaz, R. ve Boyraz, E. (2020). Marka Kent Konumlandırmada Algılama Haritalarının Kullanımı: Erzurum İli Örneği, Uluslararası Yönetim İktisat ve İşletme Dergisi, 16(2): 401-428.

Braun, E. (2008). City Marketing: Towards an Integrated Approach. Rotterdam: Erasmus University.

Cai, L. A. (2002). Cooperative Branding for Rural Destinations, Annals of Tourism Research, 29(3): $720-742$

Can, M. ve Başaran, K.Z. (2014). Kent Markası ve İmajının Belirlenmesi: Rize Örneği, Marmara Üniversitesi Öneri Dergisi, 11(42): 27-42.

Demirel, M. (2014). Burdur Kent İmajı: Mehmet Akif Ersoy Üniversitesi Öğrencileri Üzerine Bir Alan Araştırması-Burdur City Image: A Case Study On Mehmet Akif Ersoy University Students, Mehmet Akif Ersoy Üniversitesi Sosyal Bilimler Enstitüsü Dergisi, 6(10): 230-241.

Demirgüneş B. K. ve Avcılar, Y. (2014). Şehir Markası Oluşturma: Şehirde Oturanların Memnuniyet Düzeyleri Üzerine Bir Uygulama, 19.Ulusal Pazarlama Kongresi Bildiri Kitabı, Gaziantep, Türkiye, ss: 557-570.

Dinnie, K. (2011). City Branding: Theory and Cases. Hampshire, UK: Palgrave Macmillian Publisher Limited.

Fan, Y. (2006). Branding the Nation: What is being Branded?, Journal of Vocation Marketing, 12 (1): 5-14.

Florek, M., Hereźniak, M. and Augustyn, A. (2021). Measuring the Effectiveness of City Brand Strategy. In Search for a Universal Evaluative Framework, Cities, 110, 103079.

Gartner, W. C. (2014). Brand Equity in a Tourism Destination, Place Branding and Public Diplomacy, 10(2): 108-116.

Giritlioğlu, İ. ve Avcıkurt, C. (2010). Şehirlerin Turistik Bir Ürün Olarak Pazarlanması, Örnek Şehirler ve Türkiye'deki Şehirler Üzerine Öneriler (Derlemeden Oluşmuş Bir Uygulama), Adryaman Üniversitesi Sosyal Bilimler Enstitüsü Dergisi, 3(4):74-89.

Goeldner, C. R., Ritchie J.R. and Mcintosh, R. (2000). Tourism; Principles, Practices, Philosophies. New York: John Wiley \& Sons.

http://www.burdur.gov.tr/sehrimiz> [Erişim Tarihi: 04.03.2021].

https://burdur.ktb.gov.tr/TR-70047/kultur.html> [Erişim Tarihi: 04.03.2021].

https://cittaslowturkiye.org/\#cittaslow> [Erişim Tarihi: 14.02.2021].

Huang Chenchen, Oh K., Zhang Q. and Choi Y. (2013). Understanding the City Brand in the Regional Tourism Market Among College Students, Journal of Travel \& Tourism Marketing, 30(7): 662-671.

Işık, M. ve Erdem, A. (2015). Nasıl Marka Şehir Olunur. Konya: Eğitim Yayınevi. 
Karadă̆, A. ve Koçman, A. (2007). Coğrafi Çevre Bileşenlerinin Kentsel Gelişim Süreci Üzerine Etkileri: Ödemiş (İzmir) Örneği, Ege Coğrafya Dergisi, 16(1-2):3-16.

Kavaratzis, M., Warnaby, G. and Ashworth, G. J. (Eds.). (2014). Rethinking Place Branding: Comprehensive Brand Development for Cities and Regions. Switzerland: Springer.

Kavas, A. (2004). Marka Değeri Yaratma, Pazarlama ve İletişim Kültür Dergisi, 3(8):16-25.

Kaypak, Ş. (2013). Küreselleşme Sürecinde Kentlerin Markalaşması ve Marka Kentler, Çukurova Üniversitesi İktisadi ve İdari Bilimler Dergisi, 14(1): 335-355.

Keller, K. (1998). Strategic Brand Management: Building, Measuring and Managing Brand Equity, New Jersey: Prentice Hall Inc.

Köşker, H., Albuz, N. ve Ercan, F. (2019). Türkiye'de Turistik Talebin En Fazla Olduğu 10 Kentin Marka Kimlikleri Üzerine Bir Değerlendirme, Gaziantep Üniversitesi Sosyal Bilimler Dergisi, 18(1): 348-365.

Kotler, P. (2016). A'dan Z'ye Pazarlama. (Çeviren, Baykal, A.K.) İstanbul: Mediacat Yayıncılık.

Koumara-Tsitsou, S. and Karachalis, N. (2021). Traditional Products and Crafts as Main Elements in the Effort to Establish a City Brand Linked to Sustainable Tourism: Promoting Silversmithing in Ioannina and Silk Production in Soufli, Greece, Place Branding and Public Diplomacy, 1-11.

Law, C. (2002). Urban Tourism: Attracting Visitors to Large Cities. London: Masel Publishing Limited.

Merrilees, B., Miller, D. and Herington, C. (2009). Antecedents of Residents' City Brand Attitudes, Journal of Business Research, 62(3): 362-367.

Moon, M. ve Millison, D. (2004). Ateşten Markalar. İstanbul: MediaCat Kitapları.

Özdemir, Ş. ve Karaca, Y. (2009). Kent Markası ve Marka İmajının Ölçümü: Afyonkarahisar Kenti İmajı Üzerine Bir Araştırma, Afyon Kocatepe Üniversitesi İktisadi ve İdari Bilimler Fakültesi Dergisi, 11(2): 113-134.

Pektaş, G.Ö. ve Karadeniz, M. (2014). Kent imajının marka değeri üzerine etkisi: Gaziantep ve baklava örneği, 19. Ulusal Pazarlama Kongresi Bildiri Kitabı, 18-22.

Perry, A. ve Wisnom, D. (2003). Markanın DNA'SI. (Çeviren, Yılmaz, Z.) İstanbul: Mediacat Yayıncilik.

Tanlasa, B. T. (2005). Kentlerde Şirketler Gibi Rekabet İçinde. Marketing Türkiye, 4(83), 41-58. 